\title{
Design and Development of Kinematic and Strength Analysis of Solar Operated Multipurpose Agriculture Cutter Mechanism with Shaft Mounted Speed Reducer
}

\author{
P. D. Patil ${ }^{1}$, Prof. N. S. Hanmapure ${ }^{2}$ \\ ${ }^{1}$ Student of Master of Mechanical Engineering, Tatyasaheb Kore Institute Of Engineering \&Technology, Warananagar, Maharashtra, India \\ ${ }^{2}$ Master of Mechanical Engineering, Tatyasaheb Kore Institute of Engineering \&Technology, Warananagar, Maharashtra, India
}

\begin{abstract}
In present practice, the harvesting of vegetables by farmers is carried out manually. In this paper, here an attempt is made to reduce the man power, time and expenditure for cutting vegetables. Here automated machine is used for cutting the vegetables. This device consists of blades which are operated with the help of motor; battery is used to supply power to motor which is charged by solar panel. The kinematic linkage arrangement produces 06 cuts per minute with admit between the blades of $06 \mathrm{~mm}$ of arm. Now a days Solar is an emerging alternative energy source which ensures predictability, independence and even industrialization cost. These factors provide effectiveness for a number of agricultural applications. This mechanism of farming activity will lead to reduce labor cost which becomes extremely important in present situation.
\end{abstract}

Keywords: solar panel, kinematic linkage, pv system, Agriculture cutter

\section{Introduction}

Agriculture is an important part of the Indian economy and culture, and it can play an important role in distributed generation of energy. This project concept identifies the opportunities for solar energy use in agriculture. Farmers have the tradition of being stewards of the land, and their investment in renewable energy supports their role of protecting the land, air, and water. Solar energy, like other renewables, offers an opportunity to stabilize energy costs, decrease pollution and greenhouse gases (GHGs), and delay the need for electric grid infrastructure improvements. Solar energy systems have low maintenance costs, and the fuel is free once the higher initial cost of the system is recovered through subsidies and energy savings (from reduced or avoided energy costs). Solar panels have been recently developed and the most prominent way to produce on-farm renewable energy for pumping water on farms. Agriculture hosted some of the first terrestrial photovoltaic (PV) applications of solar energy, as it found uses for solar in remote locations around ranches and farms. Early on, solar electric made economic sense for a number of low power agricultural needs when running utility lines to a specific location was either not possible or too expensive.

\section{Literature Review}

1. James E. Edgell, etal ${ }^{[1]}$, worked in cordless electric grass shear. A battery operated grass shear incorporates a low friction, flexible tooth blade adapted to slide over tough grass without stopping the cutting action and further incorporates a hollow housing having various specially disposed handle, motor and battery compartment .The invention in providing a lightweight, portable, battery powered, cordless type grass shear having apair of toothed blades formed of strips of thin, flexible, plate metal coated to reduce friction and in which each tooth of the upper blade is independently and sufficiently flexible to allow a tough grass blade to be caught and bent between an upper and a lower tooth so that such teeth may slide over such tough grass blade without jamming or stopping cutting action of the other teeth pending withdrawal of the grass blade and a further attempt at a different angle of cutting.

2. Paul A. Ketchpel, Jr., etal ${ }^{[2]}$ worked in Power driven Grass Shear. A shear for grass and the like includes a tooth plate on which is pivotally mounted a plurality of shearing members, each including a narrow and resiliently deformable blade element. The blade elements extend outwardly along the upper surface of the tooth plate, and each oscillates across one of the cutting recesses that are defined between adjacent teeth at one end of the plate. The outer ends of the blade elements are biased toward the tooth plate causing substantially point contact to exist between the cutting edges of the blade element and the side edges of the teeth as the blade elements wipe there over. Preferably, the shear is power driven, and most desirably energy is supplied by a battery housed within the body thereof.

3. R. Joshua, V. Vasu and P. Vincent ${ }^{[3]}$ has worked in „Power Sprayere which is already in use and works with fossil fuel can be converted into solar sprayers works without any fossil fuel activities. One of the major area, which finds number applications are in Agriculture Sectors. Solar energy plays an important role in drying agriculture products and for irrigation for pumping the well water in remote villages without electricity. This Technology on solar energy can be extended for spraying pesticides, Fungicides and Fertilizers etc., using Solar Sprayers. 
International Journal of Science and Research (IJSR)

ISSN (Online): 2319-7064

Index Copernicus Value (2013): 6.14 | Impact Factor (2014): 5.611

\section{Theoretical and FE Analysis}

In this various components are used in solar cutter 1.Worm gear and worm wheel:

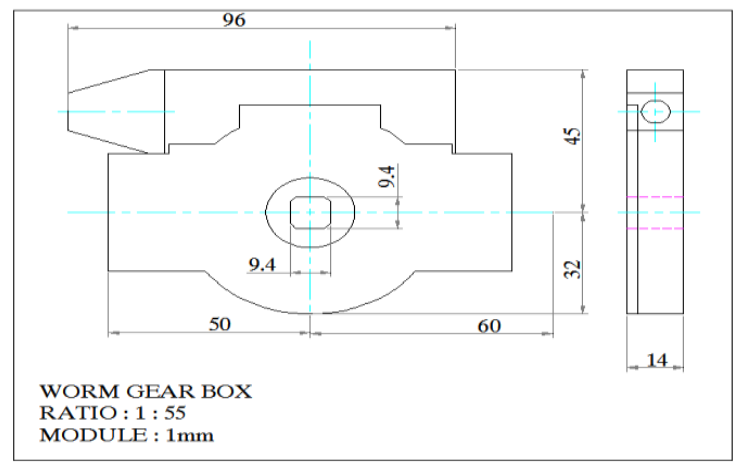

Figure 1

Speed ratio $(\mathrm{I})=\mathrm{z} 2 / \mathrm{z} 1=55$

$\mathrm{N} 1=5060 \mathrm{rpm}$

$\mathrm{N} 2=5060 / 55=92 \mathrm{rpm}$

Pitch circle diameter of worm wheel $(\mathrm{d} 2)=\mathrm{m}^{*} \mathrm{z} 2=55 \mathrm{~mm}$

Lead angle(U)

$\tan \mathrm{U}=\mathrm{z} 1 / \mathrm{q}=5.71^{\circ}$

Face width $(\mathrm{F})=2 \mathrm{~m}+\sqrt{ }(\mathrm{q}+1)=6.63 \mathrm{~mm}$

Outside diameter of the worm $(\mathrm{da} 1)=\mathrm{m}(\mathrm{q}+2)=12 \mathrm{~mm}$

Clearance $(\mathrm{C})=0.2 \mathrm{~m} \cos \mathrm{U}=0.3$

$\mathrm{Lr}=\{\mathrm{da} 1+2 \mathrm{C}\} \operatorname{Sin}^{-1}[\mathrm{~F} / \mathrm{da} 1+2 \mathrm{c}]$

$=403.27 \mathrm{~mm}$

For case hardened steel, $\mathrm{Sb}=28.2$

For Nylon-66, $\mathrm{Sb}=0.62$

$\mathrm{Xb} 1=0.25 \mathrm{Xb} 2=0.48$

$\mathrm{Mt}_{1}=17.65 \mathrm{Xb}_{1} \mathrm{Sb}_{1} \mathrm{~m} \mathrm{Lr} \mathrm{d} \mathrm{d}_{2} \cos \mathrm{U}$

$=2.749 \times 10^{5} \mathrm{~N}-\mathrm{mm}$

$\mathrm{Mt}_{2}=17.65 \mathrm{Xb}_{2} \mathrm{Sb}_{2} \mathrm{~m} \mathrm{Lr} \mathrm{d}_{2} \cos \mathrm{U}$

$=60.4 \times 10^{3} \mathrm{~N}-\mathrm{mm}$

Thus theoretical torque transmitting capacity of Nylong 66 worm gear is close to $60.4 \mathrm{~N}-\mathrm{m}$ where as the stall torque of the motor is $9 \mathrm{~N}-\mathrm{m}$ Thus the worm gear of nylon-66 is theoretically safe to transmit the given power and torque for the power window application $60.4 \times 10^{3} \mathrm{~N}$

\section{FE Analysis}

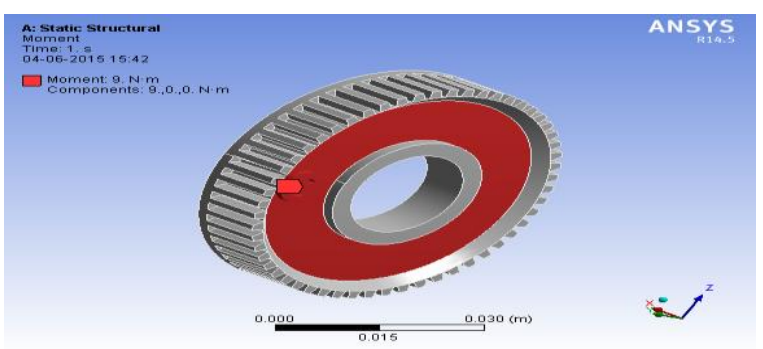

Figure 2: Boundary condition for gear

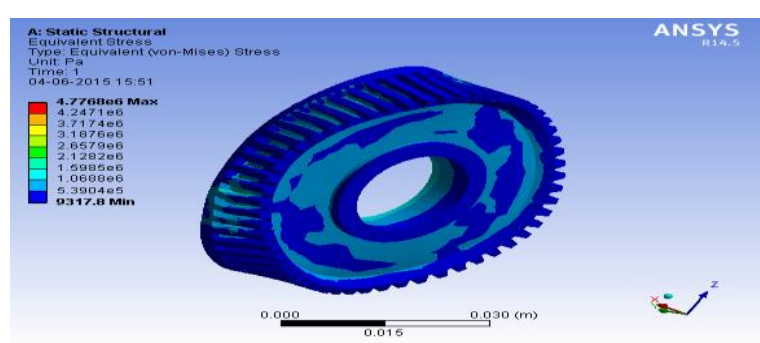

Figure 3: Von mises stress

\section{Result}

a) Maximum stress induced $=47.788 \mathrm{~N} / \mathrm{mm} 2<55 \mathrm{~N} / \mathrm{mm} 2$ (allowable value for Nylon-66 material) hence the gear is safe even at stalling torque.

b) Maximum deformation is $2.38 \mathrm{x}$ e $-7 \mathrm{~mm}$ which far below the measurable value hence no visible deflection found in the gear

2. Eccentric Arrangement

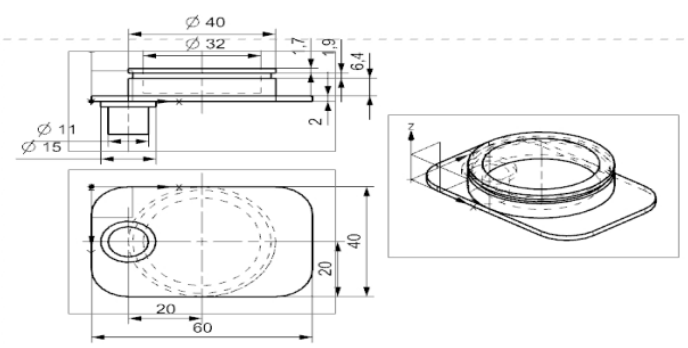

Figure 4

Material Selection

\begin{tabular}{|c|c|c|}
\hline Designation & $\begin{array}{c}\text { Ultimate Tensile } \\
\text { Strength } \mathrm{N} / \mathrm{mm}^{2}\end{array}$ & $\begin{array}{c}\text { Yeild Strength } \\
\mathrm{N} / \mathrm{mm}^{2}\end{array}$ \\
\hline EN 24 & 900 & 780 \\
\hline
\end{tabular}

$\mathrm{fS}_{\max }=\mathrm{UTS} / \mathrm{FOS}=900 / 2=450 \mathrm{~N} / \mathrm{mm}^{2}$

This is the allowable value of shear stress that can be induced in the shaft material for safe operation.

Check for torsional shear failureof shaft.

$\mathrm{Td}=\Pi / 16 \mathrm{xfs}_{\mathrm{act}} \times \mathrm{d}^{3}$

$\mathrm{fs}_{\text {act }}=16 \times \mathrm{Td}$

$\Pi \mathrm{x} \mathrm{d}{ }^{3}$

$=16 \times 16.3 \times 10^{3}$

$\Pi x(12)^{3}$

$\mathrm{fs}_{\text {act }}=48.04 \mathrm{~N} / \mathrm{mm}^{2}$

As $\mathrm{fs}_{\mathrm{act}}<\mathrm{fs}_{\text {all }}$ eccentric is safe under torsional load 


\section{International Journal of Science and Research (IJSR) \\ ISSN (Online): 2319-7064}

Index Copernicus Value (2013): 6.14 | Impact Factor (2014): 5.611

FE Analysis

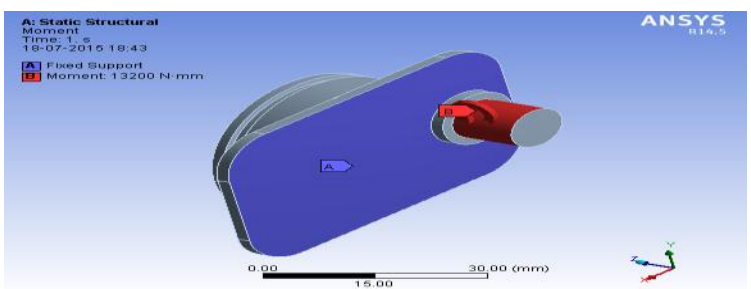

Figure 5: Boundary condition for eccentric

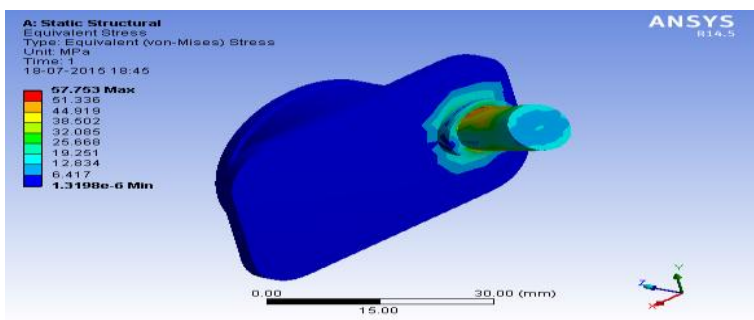

Figure 6: Von mises stress on eccentric

Result

\begin{tabular}{|c|c|c|c|c|}
\hline \multirow{3}{*}{ Part Name } & $\begin{array}{c}\text { Maximum } \\
\text { theoretical } \\
\text { stress } \\
\mathrm{N} / \mathrm{mm}^{2}\end{array}$ & $\begin{array}{c}\text { Von- } \\
\text { mises } \\
\text { stress } \\
\mathrm{N} / \mathrm{mm}^{2}\end{array}$ & $\begin{array}{c}\text { Maximum } \\
\text { deformation } \\
\text { Mm }\end{array}$ & Result \\
\hline ECCENTRIC & 48.04 & 57.75 & 0.0072 & Safe \\
\hline
\end{tabular}

3. HSS Blade



Figure 7

Material Selection

\begin{tabular}{|c|c|c|}
\hline Designation & Tensile Strength $\mathrm{N} / \mathrm{mm}^{2}$ & $\begin{array}{c}\text { Yield } \\
\text { Strength }\end{array}$ \\
\hline HSS (S-400) & 1200 & 1080 \\
\hline
\end{tabular}

$\mathrm{fc}$ act $=\mathrm{W} / \mathrm{A}$

$=407.5 / 16 * 3.2$

$=7.95 \mathrm{~N} / \mathrm{mm} 2$

As $\mathrm{fc}$ act $<\mathrm{fc}$ all bracket is safe in compression

FE Analysis

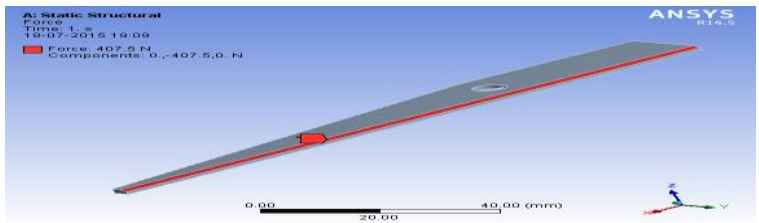

Figure 8: Boundary condition for blade

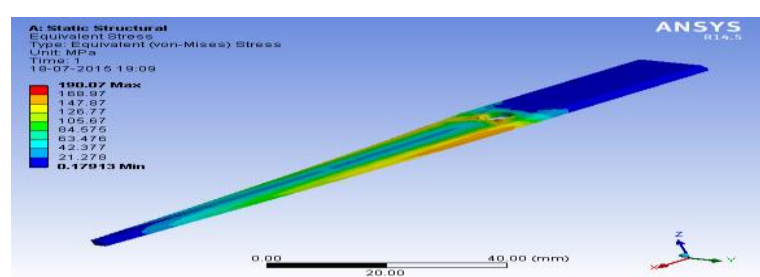

Figure 9: Von mises stress

\section{Result}

\begin{tabular}{|c|c|c|c|c|}
\hline $\begin{array}{c}\text { Part } \\
\text { Name }\end{array}$ & $\begin{array}{c}\text { Maximum } \\
\text { theoretical } \\
\text { stress } \\
\mathrm{N} / \mathrm{mm}^{2}\end{array}$ & $\begin{array}{c}\text { Von- } \\
\text { mises } \\
\text { stress } \\
\mathrm{N} / \mathrm{mm}^{2}\end{array}$ & $\begin{array}{c}\text { Maximum } \\
\text { deformation } \\
\text { Mm }\end{array}$ & Result \\
\hline BLADE & 7.95 & 190 & 0.607 & Safe \\
\hline
\end{tabular}

\section{Result and Discussion}

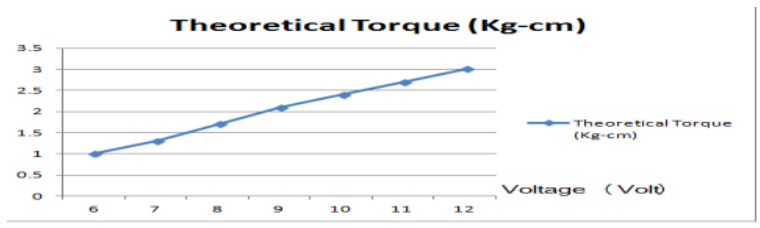

Figure 10

Graph shows that with the drop in voltage the theoretical torque drops thereby indicating drop in cutting capacity of the cutter. Thus it is recommended that the battery be properly charged to obtain maximum cutting capacity from the cutter.

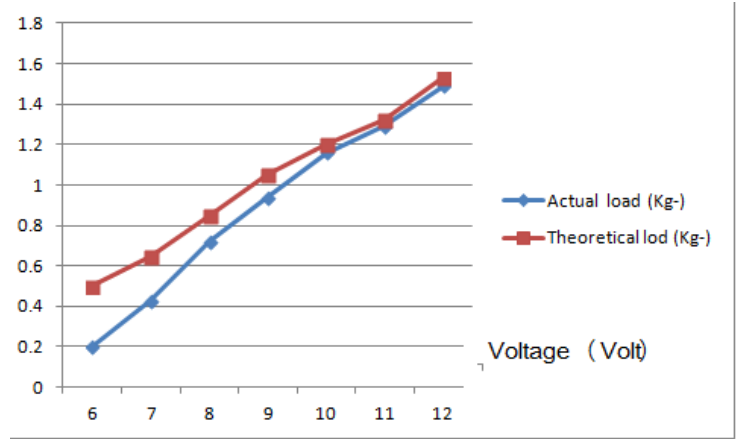

Figure 11

Comparative graph of Theoretical load an actual load indicates that at full voltage ie 11 to 12 volt the cutting load is close to the theoretical load but with the decrease in voltage the actual load drops slightly than the theoretical load indicating in-efficiency of the cutter mechanism at low voltage. Thus it is recommended that the battery be properly charged to obtain maximum cutting capacity from cutter. Thus it is recommended that the battery be properly charged to obtain maximum cutting capacity from the cutter.

\section{References}

[1] James E. Edgell, Bradford Woods, and Daniel A. Maniero, Pittsburgh, Pa., and William C. Albertson, "Cordless Electric Grass Shear" ( Filed Nov. 7, 1969, Ser. No. 874, 864 Int. Cl. B261) 19/02) 


\section{International Journal of Science and Research (IJSR) \\ ISSN (Online): 2319-7064}

Index Copernicus Value (2013): 6.14 | Impact Factor (2014): 5.611

[2] Paul A. Ketchpel, Jr., Simsbury; Carl C. Stoutenberg, "Power Driven Grass Shear"(Assignee: The Stanley Works, New Britain.conn. Filed: Jan. 4, 1972 Appl. No; 215, 358)

[3] R. Joshua, V. Vasu and P. Vincent, "Solar Sprayer An Agriculture Implement International Journal of Sustainable Agriculture 2 (1)

[4] Mohit Bansal, Tushar Bhatia, "Automatic Solar Powered Water Pumping Using Zigbee, Technology", International Journal of Emerging Technology and Advanced Engineering (ISSN 2250-2459, ISO 9001:2008 Certified Journal, Volume 4, Issue 4, April 2014)

[5] Hemant Ingale, N.N.Kasat, "Automated Solar Based Agriculture Pumping" International Journal of Advanced Research in Computer Science and Software Engineering (Volume 2, Issue 11, November 2012)

[6] Irene M. Xiarchos, Brian Vick, "Solar Energy Use in U.S. Agriculture Overview and Policy Issue" 